\title{
SILENCIAMENTOS E QUESTIONAMENTOS: A PESQUISA EM EDUCAÇÃO COMO INCITAÇÃO ÀS MUDANÇAS
}

A Roteiro tornou-se um periódico com publicações on-line contínuas. Essa modalidade possibilita disponibilizar à comunidade científica e acadêmica resultados de estudos e pesquisas sobre políticas e processos educacionais de forma mais célere. Isso porque os textos recomendados pelos avaliadores ad hoc e aprovados pela Comissão Editorial podem ser publicados imediatamente após sua diagramação. No entanto, continuaremos a utilizar a organização de três números anuais que podem ser disponibilizados concomitantemente. 0 sumário eletrônico e a apresentação de cada número serão disponibilizados aos leitores tão logo tivermos reunido o conjunto de textos necessários para sua composição.

0 primeiro número de 2019 nessa modalidade é composto por um conjunto de 13 artigos (quatro deles de demanda contínua e nove da seção temática), uma resenha e uma entrevista. A seção temática Educação étnico racial: desafios cotidianos para além dos aspectos legais, organizada pelo professor Elison Antonio Paim, da Universidade Federal de Santa Catarina, inaugura os números da Roteiro de 2019.

0 conjunto de textos da Seção Temática traz resultados de pesquisas sobre racismo e preconceito, focalizando especialmente os povos negros e indígenas, que compõem uma população significativa no Brasil. Um dos fios condutores das discussões e reflexões propostas é a invisibilidade e o silenciamento da história e da cultura desses grupos na educação escolar brasileira, em contraste com histórias e culturas coloniais.

Como destaca Paim (2019, p. 2), a própria "colonialidade estabeleceu o racismo como um dos princípios estruturantes e organizadores da dominação na modernidade capitalista." Baseado em distintos estudos, o autor aponta que "essa colonialidade implementada pelos europeus para com os povos africanos e americanos se traduziu na forma de colonialidade do poder, colonialidade do ser, colonialidade da natureza e especialmente a colonialidade do saber." (PAIM, 2019, p. 2). E essa colonialidade, obviamente, adentra o campo da educação, que se caracteriza pelo governo e autoridade de determinados saberes, histórias e culturas, em detrimento de outros saberes, histórias e culturas.

Os textos que compõem a seção temática deste número contribuem para a compreensão da história e da cultura dos povos afrodescendentes, mas também avançam no sentido da denúncia do seu ocultamento nos currículos escolares. Para além da obrigatoriedade das Leis n. 10.639/2003 - que estabelece a obrigatoriedade do ensino de história e cultura afro-brasileira dentro das disciplinas curriculares do ensino fundamental e médio (BRASIL, 2003) - e n. 11645/2008 - que estabelece as diretrizes e bases da educação nacional para incluir no currículo oficial da rede de ensino a obrigatoriedade da temática história e cultura 
afro-brasileira e indígena (BRASIL, 2008) -, precisamos efetivamente reconhecer, valorizar e empoderar essas culturas.

Este número da Roteiro traz, ainda, um conjunto de textos - caracterizados como artigos de demanda contínua - que abordam, respectivamente, a docência superior, instituições de ensino, políticas educacionais e políticas de formação de professores.

0 artigo Docência na educação superior: a constituição de uma docência que opera pelo agenciamento, de autoria de Daniela Pederiva Pensin, é resultado de uma pesquisa documental que, por meio de análises inspiradas em estudos foulcaultianos, problematiza a construção da docência na educação superior. A partir de análises de projetos pedagógicos de instituições de ensino superior do Rio Grande do Sul, a autora conclui que atualmente a lógica empresarial é uma referência nessas instituições, e, consequentemente, a constituição da docência nesses espaços opera pelo agenciamento. Esse agenciamento é evidenciado, entre outros aspectos, pelas exigências de práticas docentes inovadoras e empreendedoras e de produção de pesquisas e conhecimentos úteis ao desenvolvimento econômico.

Manuela Garcia de Oliveira e Virgínia Pereira da Silva de Avila, no texto Origem do Centro de Educação Rural Clementino Coelho: entre história e memória (Petrolina-PE, 19771984), apresentam resultados de uma investigação documental e de histórias de vida que resgatam a criação do referido centro educacional. 0 estudo realizado possibilitou às autoras constatar que a origem do Centro está associada ao Sistema Integrado de Educação Rural, concebido pelo Instituto Interamericano de Cooperação Agrícola, especialista em cooperação técnica para o desenvolvimento da agricultura. As autoras indicam a necessidade de estudos mais aprofundados para a compreensão do papel do Sistema Integrado de Educação Rural de Pernambuco na criação dos Centros de Educação Rural.

0 texto Políticas educacionais para o ensino médio: a inclusão educacional exclusão social como intenção e gesto, de autoria de Aparecida Favoreto, Ireni Marilene Zago Figueiredo e Roberto Antonio Deitos, trata das reformas educacionais para o ensino médio ocorridas após a Ditadura Militar brasileira. As análises tecidas evidenciam que essas reformas estiveram vinculadas ao processo de mudança tecnológica e à crise do capital, colaborando para que as renovações curriculares atendessem às diretrizes do capital nacional e internacional. Assim, mantêm-se a reprodução do capitalismo e o controle ideológico e social que respondem, de um lado, pela inclusão educacional e, de outro, pela exclusão social.

Por fim, no artigo Magistério: que lugar é esse?, de autoria de Lilian Alves Pereira e Gicele Maria Cervi, temos uma análise das políticas de formação de professores para a atuação na educação infantil e nos anos iniciais do ensino fundamental. As autoras problematizam essa formação a partir da ambiguidade da LDB de 1996 que prevê a formação em nível superior, mas não extingue a formação em nível médio - pelo curso de Magistério. 
Concluem que a política de formação de professores do Brasil não é neutra, mas resulta de jogos de interesses que se voltam, majoritariamente, para o atendimento das exigências de organismos internacionais.

Não menos importante, apresentamos também a fotografia que ilustra a capa deste número da Roteiro, registrada por Victória Holzbach, e que representa a diversidade, a alfabetização e alguns dos desafios da educação.

Que os resultados das pesquisas socializadas neste número possam servir de influxo para mudanças propositivas em nossas pesquisas e em nossas práticas, tendo em vista uma educação mais includente e uma sociedade mais democrática. Nesse sentido, almejamos que os textos aqui apresentados, ao tornarem-se apoio bibliográfico de outros pesquisadores, sejam, conforme sugere Marques (2006), inspiração, ajuda para o enfrentamento de impasses e descortinamento de novos horizontes e caminhos.

Boa leitura e reflexões aos nossos leitores.

\author{
Nadiane Feldkercher \\ Marilda Schneider \\ Priscila Monteiro Chaves
}

\title{
REFERÊNCIAS
}

BRASIL. Lei n. 10.639, de 9 de janeiro de 2003. Altera a Lei no 9.394, de 20 de dezembro de 1996, que estabelece as diretrizes e bases da educação nacional, para incluir no currículo oficial da Rede de Ensino a obrigatoriedade da temática "História e Cultura Afro-Brasileira", e dá outras providências. Diário Oficial [da] República Federativa do Brasil, Brasília, DF, 10 dez. 2003.

BRASIL. Lei n. 11645, de 10 março de 2008. Altera a Lei no 9.394, de 20 de dezembro de 1996, modificada pela Lei no 10.639, de 9 de janeiro de 2003, que estabelece as diretrizes e bases da educação nacional, para incluir no currículo oficial da rede de ensino a obrigatoriedade da temática "História e Cultura Afro-Brasileira e Indígena". Diário Oficial Idal República n. Federativa do Brasil, Brasília, DF, 11 mar. 2008.

MARQUES, M. 0. Escrever é preciso: o princípio da pesquisa. 5. ed. rev. ljui: Ed. Unijuí, 2006.

PAIM, E. A. Educação étnico racial: desafios cotidianos para além dos aspectos legais. Roteiro, Joaçaba, v. 44, n. 1, p. 1-10, jan./abr. 2019. 
